\title{
ЗАСТОСУВАННЯ ПРОГРАМНОГО КОМПЛЕКСУ FDS ДЛЯ ВИЗНАЧЕННЯ ОСЕРЕДКУ ПОЖЕЖІ
}

\section{APPLICATION OF THE FDS SOFTWARE TO DETERMINE FIRE EXCHANGE}

Цвіркун С. В., к.т.Н., доц., Удовенко М. Ю. (Черкаський інститут пожежної безпеки імені Героїв Чорнобиля НУЗУ)

S. Tsvirkun Ph.D. in Engineering, Associate Professor, M. Udovenko (Cherkassy Institute of Fire Safety named after Heroes of Chornobyl of National University of Civil Defense of Ukraine)

Розглянуто можливості використання розрахункових методів для визначення осередку пожежі. Розкрито зміст найбільш часто використовуваних розрахункових методів при визначенні осередку пожежі. Запропоновано порядок дій для коректного проведення розрахунків з використанням методів математичного моделювання програмним комплексом Fire Dynamics Simulator (FDS).

One of the main tasks of the forensic fire investigation is identifying a seat of fire. In the process of identifying a seat of fire, the following circumstances should be taken into account:

- the seat of fire is characterized by an area of maximum burning duration;

- the degree of thermal damage to structures and materials in the area of seat of fire is usually higher than in other areas;

- to a large extent, the nature of the burning escalation depends on the location of the primary burning;

- when identifying the location of a possible seat of fire, the features of processes occurring during the fire, which may affect its onset and escalation, should be taken into account.

Currently, in most cases, an expert takes these factors into account subjectively, without applying any calculation methods. However, the application of such methods can increase the reliability and quality of the investigations carried out to determine the seat of fire. 
The main calculation methods that can be used in identifying the seat of fire are as follows:

- calculations based on the reconstruction of fire escalation (temporary fire characteristics);

- calculations of temperature fields on the structures (temperature characteristics of a fire);

- calculations of the parameters of processes occurring during a fire.

These calculations should be supplementary to the conventional methods of identifying a seat of fire, based on the evaluation of thermal damage to structural materials, the identification of signs of seat of fire and indications of the direction of the spread of burning, the analysis of witnesses' statements, etc.

The proposed methods for identifying the likely seat of fire using calculation techniques are innovative and still need to be finalized. However, when achieving a certain level of result accuracy, these techniques can contribute to more efficient work of experts and improve the quality of expert findings. Since various hazardous factors and their impact on building structures are taken into account during modelling, the proposed techniques will be useful for the analysis of large-scale fires or fires in buildings with complex structural solutions.

Ключові слова: осередок пожежі, розрахункові методи, моделювання розвитку пожежі, Fire Dynamics Simulator.

Keywords: seat of fire, calculation methods, fire spreading modeling, Fire Dynamics Simulator

Вступ. Одним з основних завдань судової пожежно-технічної експертизи є визначення осередку пожежі. У процесі виявлення осередку необхідно враховувати наступні обставини:

- у зв'язку з тим, що осередок пожежі $є$ місцем первинного виникнення горіння то, для його визначення слід виявити зону найбільшої тривалості горіння;

- при відносно рівномірному розподілі пожежного навантаження, внаслідок більш тривалого горіння, в осередкової зоні ступінь термічного ураження конструкцій та матеріалів, як правило, вище, ніж в інших зонах;

- характер розвитку горіння в значній мірі залежить від місця розташування первинного виникнення горіння; 
- при пошуку осередкових зон необхідно враховувати особливості процесів, що відбуваються під час пожежі, які можуть впливати на його виникнення і розвиток.

Зазначені фактори в даний час в більшості випадків враховуються експертом суб'єктивно без застосування розрахункових методик. Разом 3 тим застосування цих методик може підвищити достовірність і якість проведених досліджень щодо визначення осередку пожежі. До основних розрахункових методів, які можуть застосовуватися при визначенні осередку пожежі, відносяться наступні:

- розрахунки із реконструкції розвитку пожежі (тимчасові характеристики пожежі);

- розрахунки температурних полів на конструкціях (температурні характеристики пожежі);

- розрахунки параметрів процесів, що протікають при виникненні пожежі.

Проведення таких розрахунків має супроводжувати традиційні методи встановлення осередку пожежі, засновані на оцінці термічних уражень матеріалів конструкцій, виявленні осередкових ознак і ознак спрямованості поширення горіння, аналізі показань свідків та ін.

Розглянемо докладніше практичне застосування перерахованих розрахункових методів для визначення осередку пожежі.

Визначення осередку пожежі з проведенням розрахунків із реконструкції розвитку пожежі. Суть розрахунку полягає у виборі місця імовірного осередку пожежі, джерела запалювання та реконструкції виникнення пожежі. Місце осередку пожежі може вважатися встановленим, якщо розрахункові дані щодо розвитку пожежі в часі, просторі і його наслідки співпадають 3 фактичними даними. Для цього необхідно виконати наступні основні етапи:

- розробити сценарії пожежі, на основі даних про іiі розвиток, що включають як об'єктивні, так і суб'єктивні дані;

- на основі розробленого сценарію і представлених матеріалів визначити вихідні дані (початкові умови) для моделювання i провести моделювання;

- провести оцінку отриманих в результаті моделювання даних 3 наявними об'єктивними i суб'єктивними даними про розвиток пожежі; 
- при збігу даних прийняти версію про виникнення пожежі в даному місці. В іншому випадку розробити альтернативний сценарій і повторити розрахунок.

Для проведення розрахунків на основі польового моделювання може бути використаний програмний додаток Fire Dynamics Simulator (FDS) [1]. Перевагами цього програмного додатку $є$ його безкоштовність та можливість проведення розподілених розрахунків на декількох комп'ютерах. Розрахунок параметрів пожежі проводиться методом, аналогічним до викладеного в методиці [2].

При розробці сценарію пожежі визначаються межі об'єкта що досліджується, розподіл пожежного навантаження на об'єкті i послідовність подій під час пожежі (розташування осередку пожежі, спрацьовування систем пожежогасіння, димовидалення, стану вікон, дверей і т.п.). Одночасно $з$ цим здійснюється фізична постановка задачі, тобто проводиться формулювання початкових $\mathrm{i}$ граничних умов, а також проводиться створення інформаційного поля про властивості пожежного навантаження (теплофізичні характеристики речовин i матеріалів, характеристики горіння об'єктів).

Результатом проведеної роботи буде створення файлу 3 вихідними даними для коректної роботи розрахункового пакету FDS. Під час розрахунку визначається сукупність полів швидкостей, температур і концентрацій газів для всього часового інтервалу процесу горіння. Для візуалізації результатів розрахунків використовується спеціальне програмне забезпечення постпроцесор SmokeView.

Таким чином, експерт отримує докладну візуалізовану картину розвитку горіння. Якщо реконструйована картина в будь-якому аспекті (динаміці або спрямованості розвитку горіння, наслідки пожежі і т.д.) не узгоджується 3 достовірно відомими обставинами пожежі та іншими реаліями (за умови, що всі характеристики i граничні і початкові умови вказані коректно) експерту слід розглянути провести моделювання інших сценаріїв розвитку пожежі.

Отримані результати розрахунку можуть бути включені до експертного висновку.

Для розрахунку небезпечних чинників пожежі взагалі можливе використання узагальнених даних відповідно до $[3,4]$. 
Однак слід мати на увазі, що моделювання пожежі за допомогою розрахункових методів (польового моделювання) не відображає реальні процеси у повному обсязі, що обумовлено складністю врахування усіх наявних деталей і подій. При цьому існує пряма залежність: чим точніше вихідні дані для проведення моделювання i чим вище знання експерта, тим точніше реконструйований сценарій пожежі відповідатиме реальному процесу. Крім того, застосування таких програмних комплексів доцільно для пожеж на складних об'єктах, а також на пожежах, що супроводжуються загибеллю людей чи великими матеріальними збитками, що пов'язано з проведенням великої підготовчої роботи із підготовці вихідних даних для розрахунку.

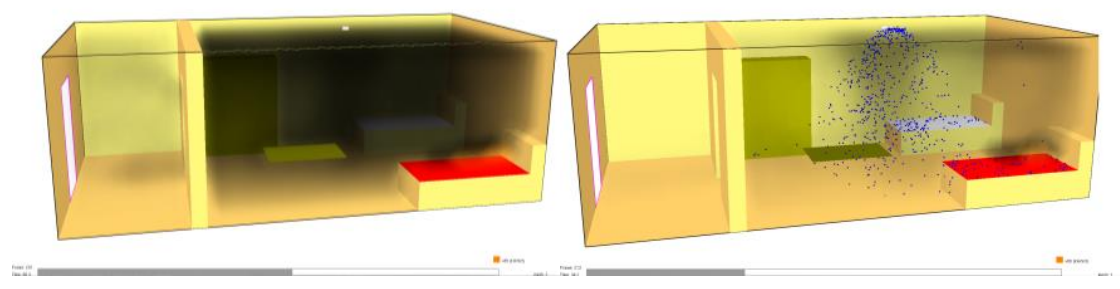

Рис.1. Моделювання роботи систем димовидалення і пожежогасіння

Визначення осередку пожежі з використанням розрахунків температурних полів на конструкціях. Сутність розрахунку полягає в тому, що виходячи з геометрії приміщень, розподілу пожежного навантаження, необхідно визначити ймовірне місце знаходження осередку пожежі. Після проведення моделювання пожежі, отримані результати розрахунку порівнюються 3 реальними термічними ураженнями, і приймається постанова про правомірність судження про передбачуване місце знаходження осередку пожежі. При цьому послідовність дій, які необхідно провести для визначення осередку пожежі даними способом, в загальному випадку, збігаються 3 послідовністю дій, зазначених для попереднього методу.

Одним $з$ важливих аспектів, на який слід звернути особливу увагу, при використанні даного розрахункового методу визначення осередку пожежі, $є$ коректність визначення зон термічних уражень. 3 цього також випливає, що застосування даного методу виправдане лише в тих випадках, коли має місце можливість встановлення 
однієї або декількох яскраво виражених зон термічних уражень, а проведення розрахунків для них дозволить 3 достатнім ступенем впевненості підтвердити версію про знаходження осередка пожежі в одній з них.

При визначенні зон термічних уражень частіше за все використовуються візуальні методи визначення термічних уражень. Однак слід зазначити, що при їх простоті і доступності вони є найменш точними. Традиційно при використанні візуального методу оцінюються такі параметри, як деформації, вигоряння, відшарування захисного шару бетону, штукатурки, наявність або відсутність кіптяви та ін.

При цьому для підвищення надійності даних, які отримуються при оцінюванні зон термічних уражень, необхідно прагнути до використання найбільш точних методів, наявних у розпорядженні експерта, в комбінації з візуальними методами.

В більшості випадків для охарактеризування ступеню термічного ураження матеріалу на пожежі використовуються такі фізичні параметри, які описують структуру, склад і властивості матеріалу, які монотонно змінюються зі збільшенням температури $і$ тривалості теплового впливу і можуть бути 3 достатньою точністю виміряні за допомогою сучасних вимірювальних інструментів. До таких параметрів, зокрема, слід віднести величину коерцитивної сили для холоднодеформованих сталевих виробів (магнітний метод), електроопір для карбонізованих залишків деревини та полімерних матеріалів, співвідношення характеристичних смуг в IЧ спектрах або рентгенівських дифракційних максимумів, залишкового вмісту термолабільних компонентів для кам'яних неорганічних матеріалів, виготовлених випалювальних методом i iн.

Однак функціональні залежності зазначених параметрів від умов теплового впливу дуже різні, більш того, одні 3 них зі збільшенням температури i тривалості нагріву послідовно зростають, інші - послідовно знижуються. 3 метою компенсації цього ефекту доцільно використовувати залежності, що визначають відносні значення ступеня термічного ураження будь-якого матеріалу пожежі, які розраховуються щодо значень мінімальної та максимальної ступеня руйнування розглянутого матеріалу на цій пожежі. При цьому результат повинен знаходитися в інтервалі від нуля до одиниці. 
Після проведення моделювання та отримання полів значень необхідно провести порівняння отриманих даних з реальними.
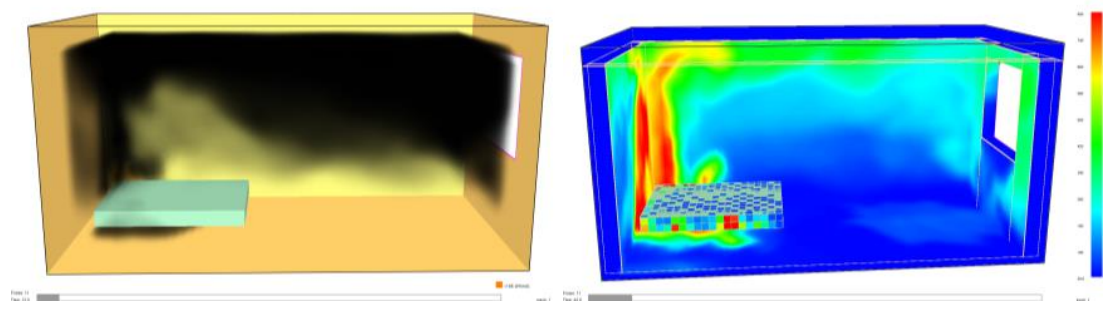

Рис. 2. Моделювання пожежі та візуалізація теплових полів

При визначенні осередка пожежі методом реконструкції процесу горіння може проводитися порівняння реальних термічних уражень 3 розрахунковими. При їх співпадінні можна зробити висновок про правильність сценарію розвитку пожежі i про місцезнаходження вогнища пожежі.

При визначенні осередку пожежі методом порівняння термічних уражень виявлення ознак осередку пожежі може здійснюватися наступним чином. Передбачається, що будь-які ділянки приміщення можуть бути осередком пожежі з однаковою ймовірністю. Тому при розрахунку використовується модель одночасного горіння всього пожежного навантаження по поверхні 3 розрахунком розподілу температурних зон (безрозмірних температур). Далі, порівнюючи його 3 розподілом ступеня термічних уражень можна виявити зони значних фактично термічних уражень, при цьому відсутні високі значення розрахункових термічних уражень. Отже, горіння в цих зонах було більш тривалим, ніж в інших, що викликало більш сильне нагрівання цих зон.

Допоміжні методи математичного моделювання, що використовуються при визначенні осередку пожежі

Розрахунки передачі тепла теплопровідністю. Як відомо, тепло може передаватися шляхом теплопровідності, конвекції i променистого теплообміну. Метою дослідження при визначенні осередку пожежі 3 використанням розрахунків передачі тепла теплопровідністю є отримання значень температури на поверхні що 
не нагрівається і порівняння її з критичної для оцінки можливості загоряння матеріалів від нагрівання.

Такий розрахунок може проводитися, наприклад, для оцінки можливості загоряння конструкцій, прилеглих до пічним димоходів, при прогріванні за рахунок теплопровідності і ін.

Для моделювання, наприклад горіння дров, може використовуватися горіння деревних матеріалів з бази даних FDS. Для вимірювання температур можна використовувати віртуальні датчики в газовій i твердій фазі. Для візуалізації та аналізу результатів можна використовувати зрізи (SLICES) і графіки, які вказують значення датчиків в різні моменти часу [5] .
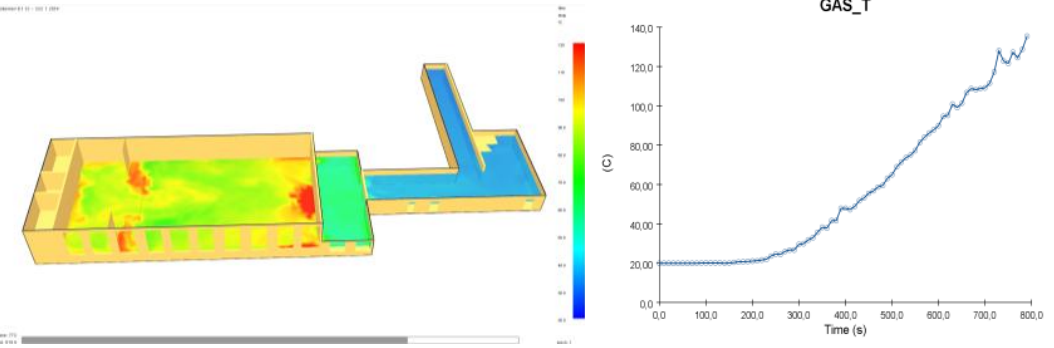

Рис. 3. Візуалізація результатів моделювання

Розрахунки передачі тепла конвекиією $i$ променистим теплообміном. Метою розрахунку є визначення температури на поверхні об'єкта, що обігрівається променистим і конвективним тепловим потоком, 3 метою порівняння іiі 3 критичною і оцінки можливості загоряння матеріалів від нагрівання. Такий розрахунок може проводитися, зокрема, для оцінки можливості загоряння будівель від пожежі в інших будівлях, і розвитку, таким чином, пожежі з утворенням вторинних вогнищ.

Для моделювання пожежі в пакеті FDS можна використовувати дані про пожежне навантаження 3 методичного посібника [3]. Для візуалізації та аналізу результатів можна використовувати перетини і віртуальні датчики теплового потоку в газовій фазі. Порівняння значень фактичних параметрів з їх критичними значеннями і оцінка результатів може проводитися відповідно до [4].

Слід зазначити, що таким же чином може розглядатися виникнення пожежі від електричних або фрикційних іскор, а також гарячих частинок, що виникають під час пожежі. 

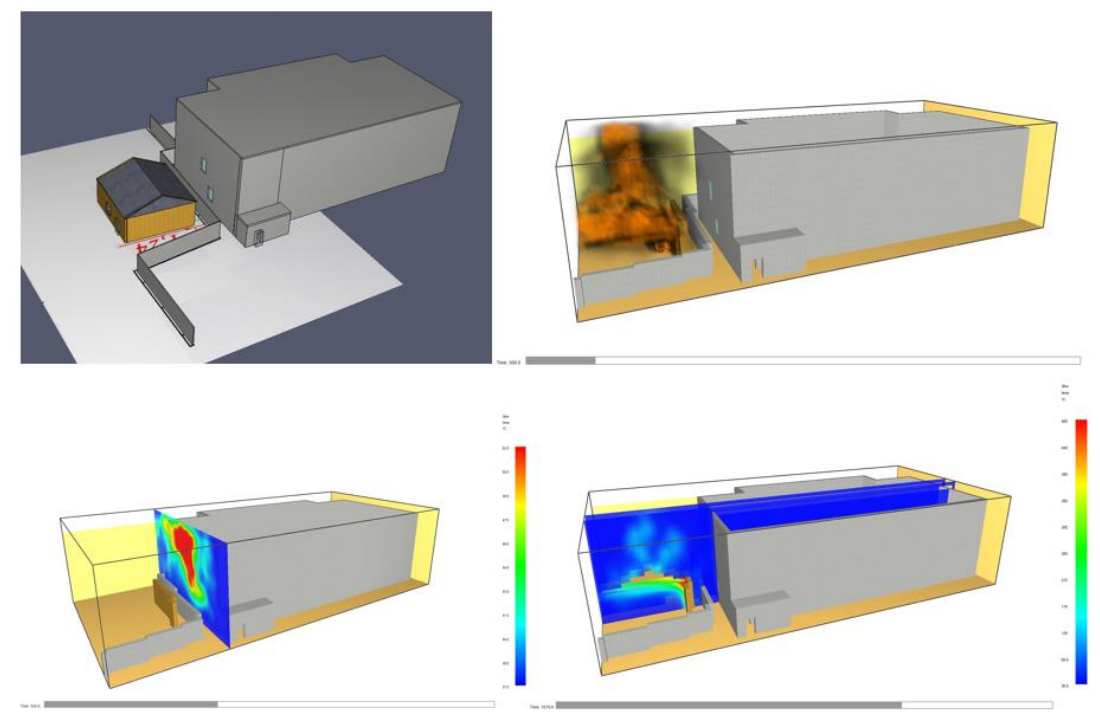

Рис. 4. Моделювання можливого розповсюдження пожежі

Розрахунки при загальному спалаху

Для оцінки часу виникнення пожежі слід враховувати різні чинники, що впливають на швидкість розвитку пожежі. Так, одна й та ж сама пожежа може проходити різні стадії розвитку, які можуть відрізнятися. Для моделювання таких процесів при вирішенні задач про визначення осередку пожежі i аналізі розвитку пожежі 3 імовірного осередку також може застосовуватися пакет FDS.

Одним 3 механізмів інтенсифікації горіння може бути раптовий доступ кисню, викликаний відкриттям дверей або розбивання вікон внаслідок нагріву (так званий «ефект сауни» або «зворотня тяга». Такий механізм характерний для так званої пожежі, регульованою вентиляцією.

Як відомо, в залежності від співвідношення кількості кисню і пожежного навантаження (горючих речовин i матеріалів) в приміщенні розрізняють два основні режими пожежі - пожежа, регульована навантаженням (ПРН) i пожежа, регульована повітрообміном (ПРП).

При ПРН кількість кисню, що знаходиться всередині закритого приміщення, досить для підтримання горіння, і розвиток пожежі лімітується кількістю залученого в процес горіння пожежного 
навантаження. Тому при ПРН приплив повітря не робить помітного впливу на процес горіння.

При ПРП кількість кисню, навпаки, недостатня для повного залучення пожежного навантаження i газоподібних горючих продуктів його термічного розкладання в процесі горіння. Розвиток пожежі лімітується припливом кисню. Тому при ПРП приплив повітря підвищує інтенсивність горіння.

В пакеті FDS такий механізм інтенсифікації горіння моделюється наступним чином. Слід розставити віртуальні датчики, що реагують на підвищення температури. При досягненні певного значення температури вікно або двері «розбиваються» та відбувається інтенсифікація горіння внаслідок припливу кисню. В результаті моделювання часових параметрів розвитку пожежі можна зрозуміти, який шлях і за який час пройшов фронт полум'я від вогнища пожежі до певних точок, зафіксованих інструментально або за показаннями, що дає можливість більш точного визначення осередку пожежі, шляхів і динаміки поширення горіння.

Розрахунки при пробіжці полум'я. Це явище пов'язане з тим, що в результаті дії підвищеної температури на пожежне навантаження і недостатній повітрообмін, в приміщеннях можуть накопичуватися газоподібні продукти піролізу (неповного згоряння), які за певних умов можуть загорятися. Фронт горіння може поширюватися по ним від осередка пожежі за досить короткий час після певної паузи, необхідної для накопичення продуктів піролізу. Облік таких чинників і правильний розрахунок часових параметрів пожежі також можуть сприяти правильному визначенню осередку пожежі.

Для моделювання пробіжки полум'я слід вказати конкретні параметри піролізу. Для моделювання процесів піролізу необхідна досить дрібна розрахункова сітка. Після завдання необхідних процесів слід провести математичне моделювання в пакеті FDS. Результати проходження фронту полум'я по газоподібним продуктам піролізу можна візуалізувати за допомогою параметра HRRPUV. Кольорові параметри можна відрегулювати у вкладці Dialog програми Smokeview.

Внаслідок моделювання часових параметрів розвитку пожежі можна зрозуміти, який шлях і за який час пройшов фронт полум'я від вогнища пожежі до певних точок, зафіксованих інструментально, або виходячи з показань свідків. 
Висновок. Запропоновані методики по визначенню імовірного осередку пожежі розрахунковими методами мають інноваційний характер та ще потребують доопрацювання. Але, при досягненні певного рівня точності результатів, ці методики можуть сприяти більш ефективній роботі експертів та підвищенню якості експертних висновків. Так як під час моделювання враховуються різноманітні небезпечні чинники та їх вплив на будівельні конструкції, ці методики доцільно буде використовувати для аналізу масштабних пожеж або пожеж в будівлях зі складними конструктивними рішеннями.

\section{Список використаних джерел}

1. Fire Dynamics Simulator [Електронний pecypc] https://pages.nist.gov/fds-smv/

2. Зернов С.И. Расчетные оценки при решении задач пожарнотехнической экспертизы: Учебное пособие. - М.: ЭКЦ МВД России, 1992. -88

3. Кошмарів Ю.А. Прогнозування небезпечних факторів пожежі в приміщенні: навч. посібник. М., 2000. 118 с.

4. Цвіркун С.В. Моделювання пожеж в приміщеннях та будівлях: Метод.посібник / Цвіркун С.В. ЧІПБ., 2018. 60 с.

5. Tsvyrkun Serhii Information technologies in educating fire safety specialists // XVIII INTERNATIONAL SCIENTIFIC CONFERENCE New technologies and achievements in metallurgy, material engineering, production engineering and physics, Monografie № 68, Częstochowa 2017 C. 444-450. 